\title{
Assessment for the Determination of Pile Capacity using Two Types of Loading Tests with Analytical Method and Numerical Simulation
}

\author{
Budijanto Widjaja and Shienny Lilianto
}

\begin{abstract}
The foundation is the lowest component of a structure and determines the robustness of a building. The bearing capacity of a pile is the main aspect that determines the strength of a foundation. Therefore, the bearing capacity must be carefully analyzed to avoid failure of the building. The actual bearing capacity is usually obtained using static axial loading test. This research aims to determine the ultimate bearing capacity of a bored pile with a diameter of $1,200 \mathrm{~mm}$ and a length of $50 \mathrm{~m}$ by using the reaction pile and Osterberg Cell systems. This research also compares the results with those of conventional method, field interpretation, and computer software (i.e., Plaxis and RS Pile). For the reaction pile system, the pile capacity difference between the Davisson $(2,110$ tons) and the Reese and Wright methods is $1.9 \%$ and that of RS Pile is $8.7 \%$. By contrast, for the $\mathrm{O}$-Cell system, the pile capacity difference between the Chin $(3,620$ tons) and the Reese and Wright methods is $7.9 \%$. Results show that the pile capacity of the $\mathrm{O}$-Cell system is approximately twice that of the reaction pile system. This finding can be attributed to the differences in the soil conditions of the two bored piles and the load transfer mechanism of the loading test.
\end{abstract}

Keywords-bored pile, pile capacity, reaction pile, Osterberg Cell

\section{Introduction}

Loading test is used to test the weight that can be supported by a structure. This method can confirm previous foundation design calculations. In this study, two types of static axial loading tests are conducted: reaction pile and Osterberg Cell (O-Cell).

\section{Methods}

The static load test involves the loading of static loads and the measurement of pile movements. The load is given gradually, and the pile displacement is observed. Testing is generally performed from $25 \%$ to $200 \%$ of the workload. However, the testing is conducted up to $250 \%$ or $300 \%$ of the workload in (Crowther, 1988) to optimize and control the ultimate load at strong earthquake loads.

The reaction pile system consists of five piles (Fig. 1)

Budijanto Widjaja

Parahyangan Catholic University Indonesia
This system possesses a pile in the middle as the main pile (i.e., test pile) that will be tested and compressed. The remaining four piles around it are called reaction piles, which will experience the tensile forces. As shown in Fig. 2, a hydraulic jack is placed on top of the pile cap. The hydraulic jack is used to control the load application. The displacement and the pile movement are measured by the dial gauges placed around the pile. ASTM D 1143-81 recommends clear distances of at least $2.1 \mathrm{~m}$ or 5 pile diameters between the test and reaction piles.

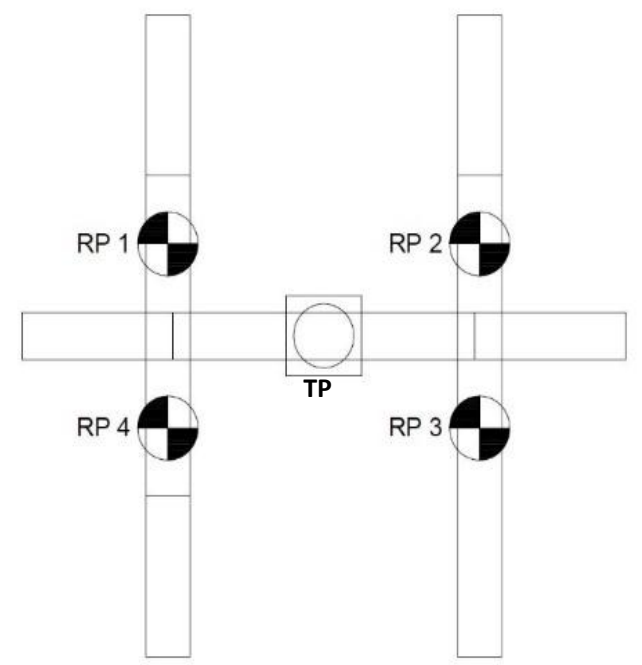

Figure 1. Top-view of the Reaction Pile System (Bauer, 2017)

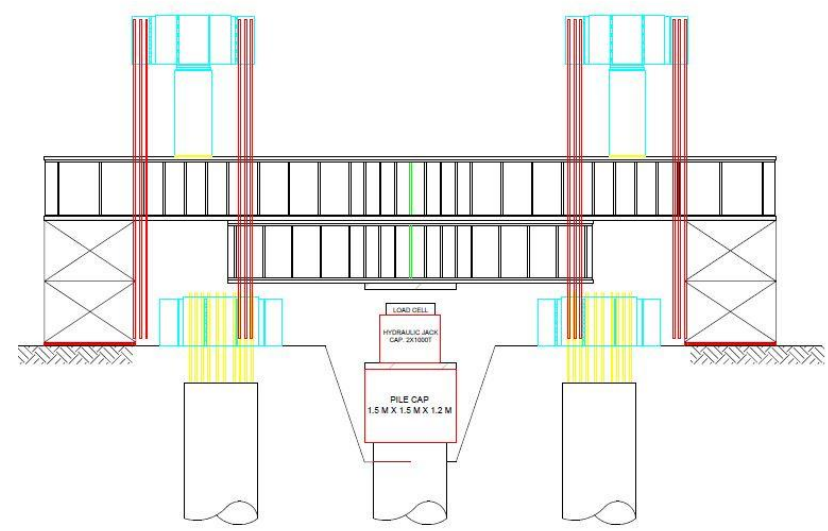

Figure 2. Side-view of the Reaction Pile System (Bauer, 2017)

Fig. 3 shows the O-Cell system (two-way static loading test or bidirectional cell test). In this system, the loading starts from the hydraulic control that applies pressure on the jack inside the foundation. This pressure expands the jack and then pushes the pile upward and downward. This test will generate two curves, namely, downward and upward 
movement load curves. To obtain the actual movement load results, the two curves are summed to form an equivalent top load curve.

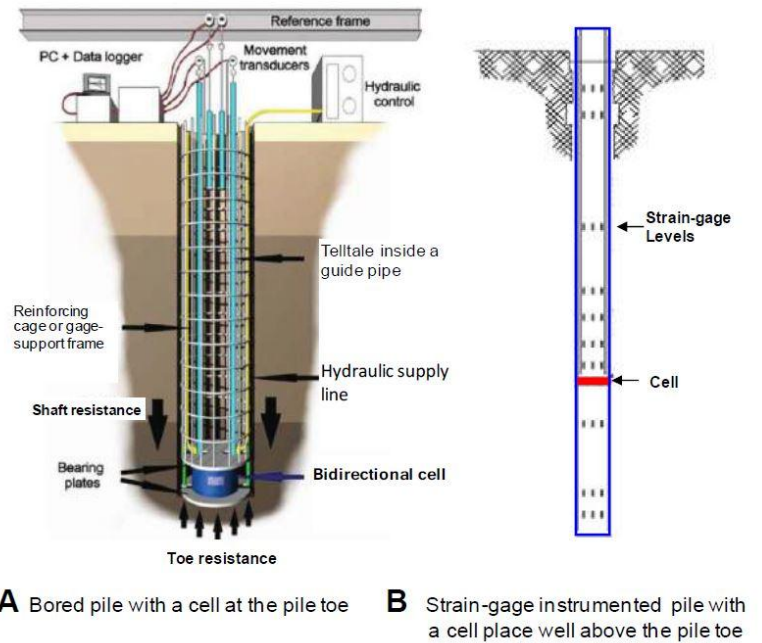

Figure 3. Osterberg cell system (Fellenius, 2017)

\section{Result and Discussion}

\section{A. Soil Stratifications and Parameters}

Fig. 4 shows the soil stratifications and parameters of $\mathrm{BH}-1$ of the reaction pile system. The system contains 10 soil layers that are dominated by clay and three layers of sand. The ground water level is at an elevation of $-3.33 \mathrm{~m}$. Fig. 5 shows the soil stratification and parameters of $\mathrm{BH}-9$ of the O-Cell system. The system contains 13 layers of soil that are dominated by clay and two layers of sand. The ground water level is at an elevation of $-3 \mathrm{~m}$.

The Poisson's ratio ( $\left.v^{\prime}\right)$ is 0.35 for effective stress condition. The elastic soil modulus for BH-1 and BH-9 uses

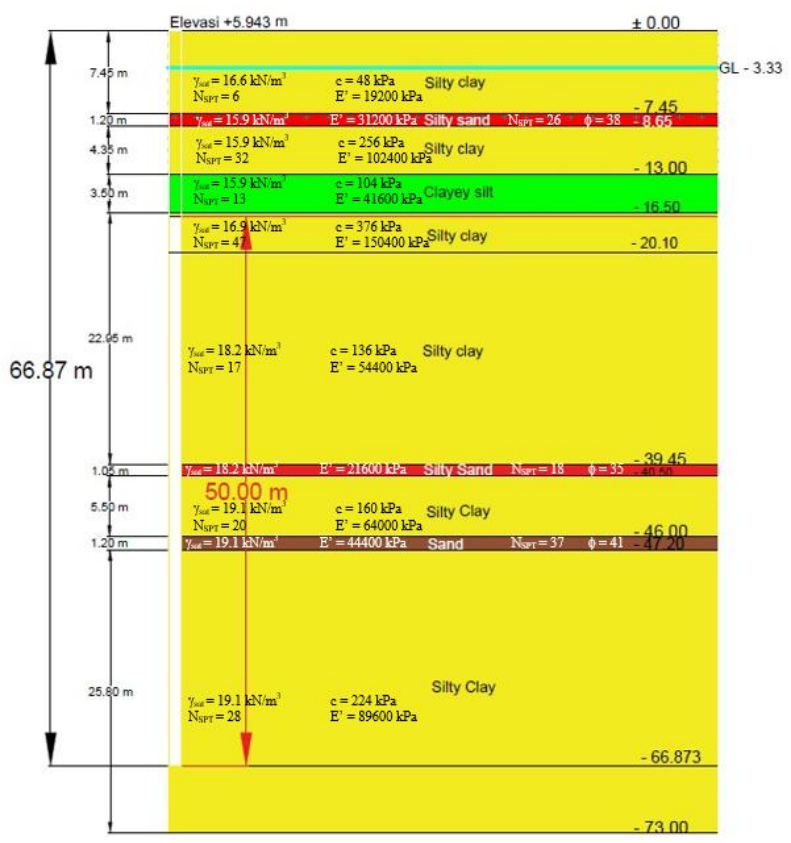

Figure 4. Soil stratification and parameters of BH-1
Eq. (1) for the sand from Peck (1974) and Eq. (2) for the clay from Duncan and Buchignani (1976).

$$
\begin{gathered}
\mathrm{E}^{\prime}(\mathrm{kPa})=(800-1200) \mathrm{N}_{\mathrm{SPT}} \\
\mathrm{E}^{\prime}(\mathrm{kPa})= \pm 0.8 \mathrm{E}_{\mathrm{u}} \\
\mathrm{E}_{\mathrm{u}}(\mathrm{kPa})=(250-500) \mathrm{c}_{\mathrm{u}}
\end{gathered}
$$

For the reaction pile system, the Poisson's ratio is 0.2 , the unit weight is $24 \mathrm{kN} / \mathrm{m}^{3}$, and the elastic modulus is 25.6 $\times 10^{5} \mathrm{kPa}$.

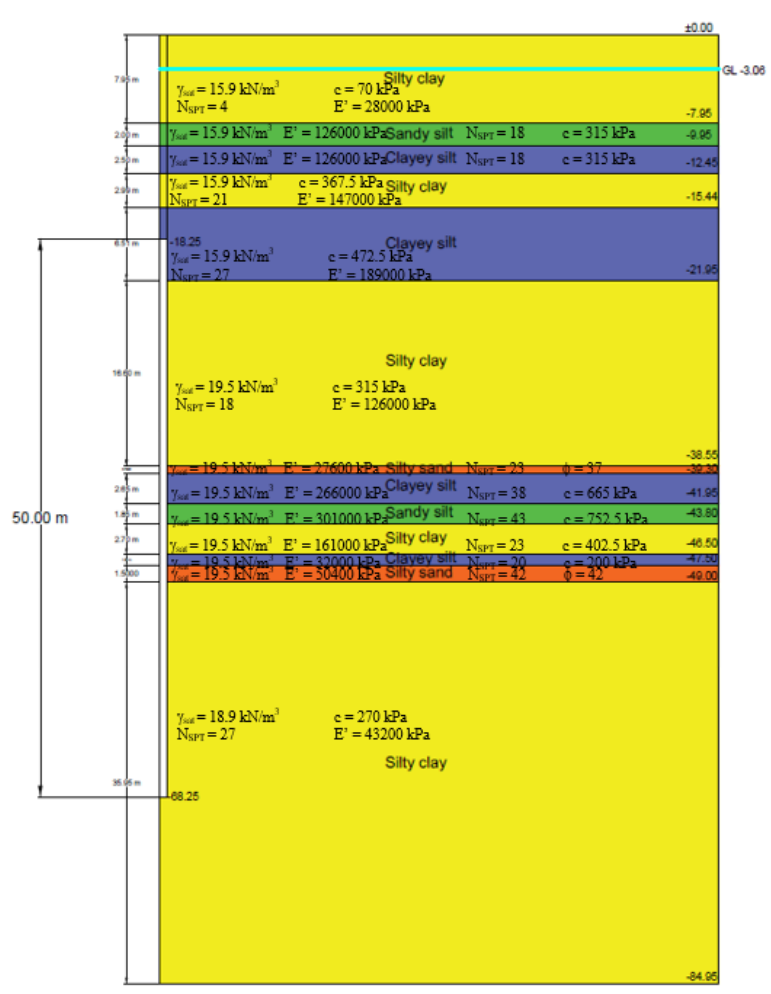

Figure 5. Soil stratification and parameters of BH-9

\section{B. Conventional Bearing Capacity Analysis}

The conventional bearing capacity is calculated using the Kulhawy (1991) and Reese and Wright (1977) methods. The adhesion factor for Reese is 0.55 . As shown in Table 1, the ultimate bearing capacity for BH-1 by the Kulhawy method is 1405.2 tons, and that by the Reese and Wright method is 2069.6 tons. Table 2 shows that the ultimate bearing capacity for BH-9 by the Kulhawy method is 1405.2 tons,

\begin{tabular}{|c|c|c|c|c|c|}
\hline \multirow{2}{*}{$\begin{array}{l}\text { End Bearing } \\
\text { Resistance } \\
\text { (ton) }\end{array}$} & \multicolumn{2}{|c|}{$\begin{array}{l}\text { Skin Friction Resistance } \\
\text { (ton) }\end{array}$} & \multirow{2}{*}{$\begin{array}{c}\text { Foundation } \\
\text { Weight } \\
\text { (ton) }\end{array}$} & \multicolumn{2}{|c|}{$\begin{array}{l}\text { Ultimate Bearing Capacity } \\
\text { (ton) }\end{array}$} \\
\hline & Kulhawy & $\begin{array}{c}\text { Reese } \\
\text { and } \\
\text { Wright }\end{array}$ & & Kulhawy & $\begin{array}{c}\text { Reese } \\
\text { and } \\
\text { Wright }\end{array}$ \\
\hline 211.7 & 1329.2 & 1993.6 & 135.7 & 1405.2 & 2069.6 \\
\hline
\end{tabular}
and that by the Reese and Wright method is 2069.6 tons.

TABLE I. Ultimate bearing capacity calculation for BH-1

\begin{tabular}{|c|c|c|c|c|c|}
\hline \multirow{2}{*}{$\begin{array}{l}\text { End Bearing } \\
\text { Resistance } \\
\text { (ton) }\end{array}$} & \multicolumn{2}{|c|}{$\begin{array}{l}\text { Skin Friction Resistance } \\
\text { (ton) }\end{array}$} & \multirow{2}{*}{$\begin{array}{l}\text { Foundation } \\
\text { Weight } \\
\text { (ton) }\end{array}$} & \multicolumn{2}{|c|}{$\begin{array}{l}\text { Ultimate Bearing Capacity } \\
\text { (ton) }\end{array}$} \\
\hline & Kulhawy & $\begin{array}{c}\text { Reese } \\
\text { and } \\
\text { Wright }\end{array}$ & & Kulhawy & $\begin{array}{c}\text { Reese } \\
\text { and } \\
\text { Wright }\end{array}$ \\
\hline 498.8 & 2660.2 & 3569.6 & 135.7 & 3023.3 & 3932.7 \\
\hline
\end{tabular}

TABLE II. Ultimate bearing capacity calculation for BH-9 


\section{Field Interpretation}

The results of field interpretation for the two systems are presented in Table 3. The interpretation uses the Davisson, Mazurkiewich, and Chin methods. The reaction pile system is in the range of 2110 tons to 2500 tons. For the O-Cell system, the range is 2650 tons to 3620 tons.

TABLE III. Results of field interpretation

\begin{tabular}{ccc}
\hline Method & Reaction Pile System & Osterberg Cell System \\
\hline Davisson Method (1972) & 2110 ton & 2650 ton \\
Mazurkiewich Method (1972) & 2500 ton & 3300 ton \\
Chin Method (1971) & 2352.9 ton & 3620 ton \\
\hline
\end{tabular}

\section{Mohr-Coloumb Model}

Using the Plaxis software and the Mohr-Coulomb model (elasto-plastic model), the interaction between pile and soil are considered in the calculation by providing the interface along the side of pile. The analysis is performed using the total multiplier and a total load of 1600 tons. The comparison of the results of Plaxis and field interpretation is presented in Fig. 6. The graph is linear. The displacement is $23 \mathrm{~mm}$ at a load of 1600 tons, and it is $22 \mathrm{~mm}$ as obtained by field interpretation. The difference is insufficiently large.

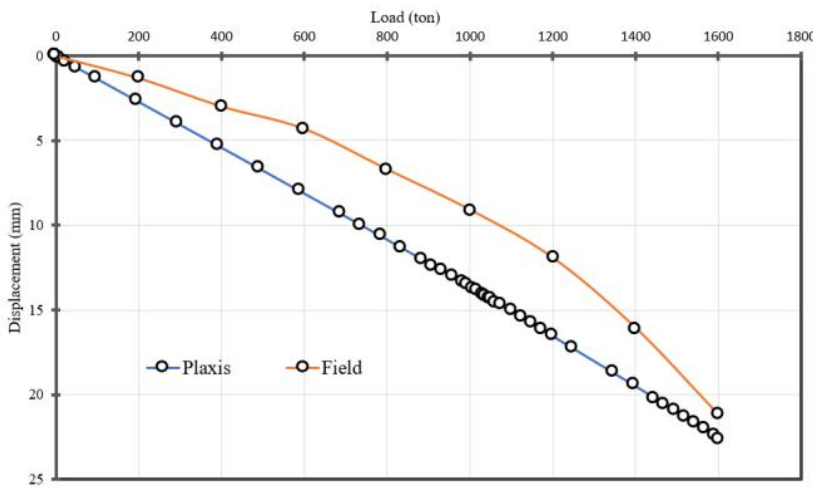

Figure 6. Comparison between the Plaxis and field results

The result for the O-Cell system generates two curves: the upward and downward movements. Fig. 7 shows the comparison between the upward and downward movements from the O-Cell system as obtained by Plaxis and field interpretation. The result is a sum of two curves. As a result, equivalent top load curve is produced. The equivalent top load curve considers the elastic pile displacement. Fig. 8 shows the comparison of the equivalent top load curves as obtained by Plaxis and field interpretation. The displacement is $15 \mathrm{~mm}$ at a load of 1600 tons for Plaxis, whereas it is 17.1

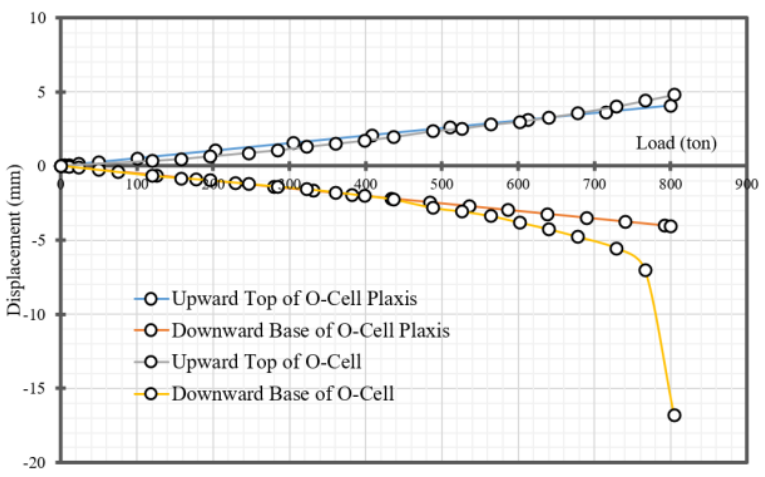

Figure 7. Comparison of the upward and downward movements of the O-Cell system $\mathrm{mm}$ for the field interpretation. The difference is sufficiently small. The graph is still linear. Thus, the ultimate bearing capacity cannot be interpreted.

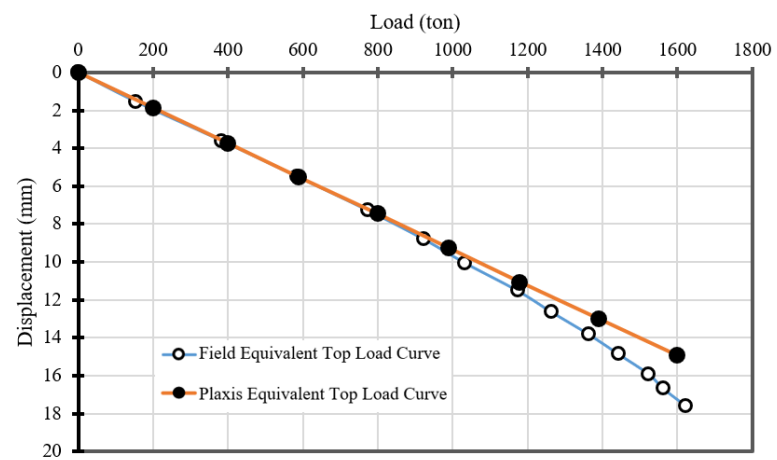

Figure 8. Comparison of equivalent top load curves

\section{E. Hardening Soil Model}

The hardening soil and Mohr-Coulomb models differ in the stiffness and power parameters. The hardening soil model uses three stiffness parameters: the triaxial loading stiffness $\left(\mathrm{E}_{50}\right)$, the triaxial unloading stiffness $\left(\mathrm{E}_{\mathrm{ur}}\right)$, and the oedometer loading stiffness $\left(\mathrm{E}_{\mathrm{oed}}\right)$. The parameters used as average values for various soil types are as follows: $\mathrm{E}_{\mathrm{ur}} \approx 3$ $\mathrm{E}_{50}$ and $\mathrm{E}_{\mathrm{oed}} \approx \mathrm{E}_{50}$, with $\mathrm{E}_{50}=\mathrm{E}$ '. The power parameter $(m)$ used is 0.5 (Brinkgreve, 2002).

Fig. 9 shows that the reaction pile graph is linear first and then becomes nonlinear. The displacement at a load of 1600 tons is $18 \mathrm{~mm}$. As shown in Fig. 10, the result of the hardening soil model for the O-Cell system is similar to that of the Mohr-Coulomb model at $15 \mathrm{~mm}$.

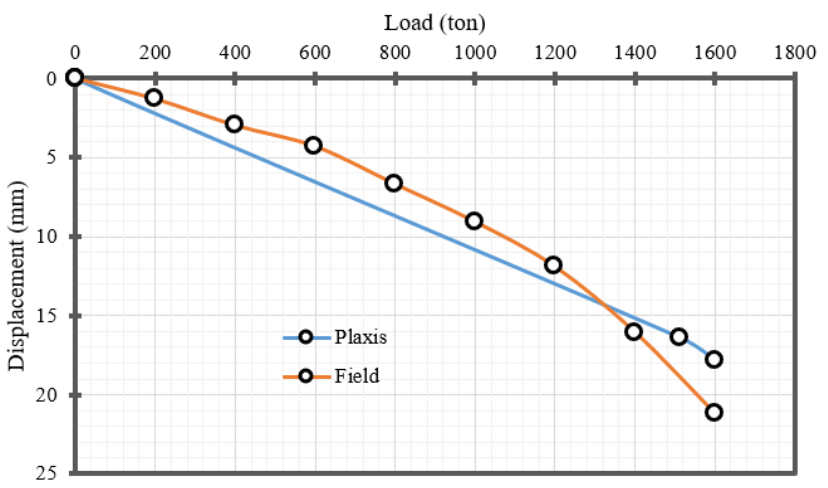

Figure 9. Comparison between the Plaxis and field results by using hardening soil model

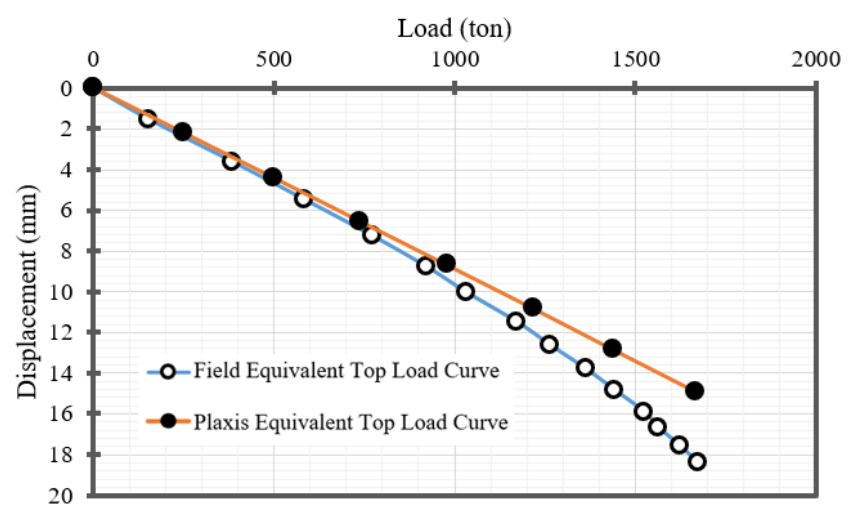

Figure 10. Comparison of equivalent top load curves 


\section{F. RS Pile}

Fig. 11 shows that the result of the RS Pile is $12 \mathrm{~mm}$ and that of the field test is $22 \mathrm{~mm}$. The bearing capacities in RS Pile by the Davisson, Mazurkiewich, and Chin methods are 2210, 2410, and 2344.3 tons.

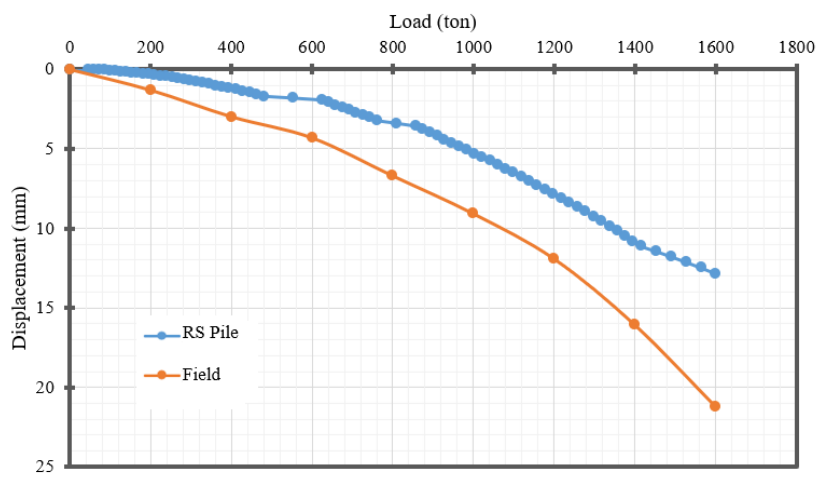

Figure 11. Comparison of RS Pile curve with the loading result of field test.

\section{Conclusion}

The bearing capacity of field interpretation for the reaction pile system by using the Davisson method (2110 tons) is close to that by the Reese and Wright method (2070 tons).

The RS Pile results show that the most approximate bearing capacity is that by the Mazurkiewich method of 1890 tons.

The difference in the bearing capacity of the reaction pile system by using the Davisson and Reese and Wright methods is $1.9 \%$. Meanwhile, the difference in RS Pile with the Reese and Wright method is $8.7 \%$.

In the reaction pile system by using the Mohr-Coulomb model in Plaxis, the displacement is similar to that in the field at $\pm 6 \%$. The displacement for the O-Cell system is also similar at $\pm 9 \%$. A difference of $\pm 15 \%$ is obtained for the reaction pile system by using the hardening soil model, whereas it is $\pm 11 \%$ for the O-Cell system. The bearing capacity cannot be determined from this result because the graph is linearly approximated.

In the O-Cell system, the bearing capacity of the Chin method of 3932.7 tons is close to that of the Reese and Wright method of 3620 tons.

The difference in load bearing capacity for the O-Cell system by the Chin method and that by the Reese and Wright method is $7.9 \%$.

The ultimate bearing capacity by the Reese and Wright method is greater than that by the Kulhawy method. The reason is that the adhesion factor used by the former is higher that of the latter for related soil conditions.

\section{References}

[1] ASTM designation: D 1143-81, Standard Test Methods for Piles Under Static Axial Compressive Load. (1989). American Society for Testing and Materials, West Conshohocken, PA 19428-2959

[2] Brinkgreve, R.B.J, \& Broere, W. (2002), Tutorial Plaxis 2D, Delft University of Technology \& Plaxis, Netherland.

[3] Bauer. (2017). Jakarta MPP Project. Bendungan Hilir, Central Jakarta.
[4] Crowther, Caroll L. (1988). Load Testing Of Deep Foundation: The Planning, Design, And Conduct Of Pile Load Test. United States, America

[5] Duncan, J.M. and Buchignani, A.L. (1976). An Engineering Manual for Settlement Studies, Report UCB/GT/81-01, Dept. of Civil Engineering, University of California at Berkeley, 94.

[6] Fellenius, Beng H. (2017). "Basics of Foundation Design Electronic Edition January 2017'. Sidney, British Columbia

[7] Peck, R.B., Hanson, W.E. and Thornburn, T. H. (1974). Foundation Engineering, Second Edition, John Wiley \& Sons, 514

About Authors:

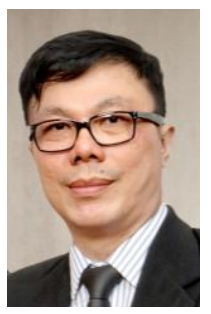

Budijanto Widjaja, Ph.D, has taught soil mechanics and geotechnical engineering at Parahyangan Catholic University, Indonesia. His research interesting is behavior of mudflow, landslides, clayshales, and numerical methods in geotechnical engineering. Nowadays, he is a director of a Center for Geotechnicalhazards $(\mathrm{C} 4 \mathrm{GH})$ and head of Department of Civil Engineering.

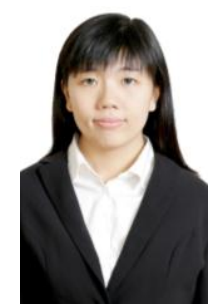

Shienny Lilianto is a student in Department of Civil Engineering, Parahyangan Catholic University. Now, she is doing a research in behavior of pile foundation. 